\title{
Labyrinthe
}

$2 \mid 1999$

Numéro 2

\section{Les vagabonds devant les tribunaux correctionnels à la fin du XIXe siècle}

Juliette Flori

\section{(2) OpenEdition}

12 Journals

\section{Electronic version}

URL: http://journals.openedition.org/labyrinthe/357

DOI: $10.4000 /$ labyrinthe.357

ISSN: 1950-6031

\section{Publisher}

Hermann

\section{Printed version}

Date of publication: 15 January 1999

Number of pages: 19-39

\section{Electronic reference}

Juliette Flori, « Les vagabonds devant les tribunaux correctionnels à la fin du XIXe siècle », Labyrinthe [Online], 2 | 1999, Online since 04 March 2005, connection on 03 May 2019. URL : http://

journals.openedition.org/labyrinthe/357 ; DOI : 10.4000/labyrinthe.357

This text was automatically generated on 3 May 2019.

Propriété intellectuelle 
Les vagabonds devant les tribunaux correctionnels à la fin du XIXe siècle

Juliette Flori 